Illinois State University

ISU ReD: Research and eData

Faculty Publications - Finance, Insurance, and

Law

Finance, Insurance, and Law

2007

\title{
The Impact of the Return to Lagged Reserve Requirements on the Federal Funds Market
}

Vladimir Kotomin

Illinois State University, vkotomi@ilstu.edu

Drew B. Winters

Texas Tech University

Follow this and additional works at: https://ir.library.illinoisstate.edu/fpfil

Part of the Finance and Financial Management Commons

\section{Recommended Citation}

Kotomin, Vladimir and Winters, Drew B., "The Impact of the Return to Lagged Reserve Requirements on the Federal Funds Market" (2007). Faculty Publications - Finance, Insurance, and Law. 16.

https://ir.library.illinoisstate.edu/fpfil/16

This Article is brought to you for free and open access by the Finance, Insurance, and Law at ISU ReD: Research and eData. It has been accepted for inclusion in Faculty Publications - Finance, Insurance, and Law by an authorized administrator of ISU ReD: Research and eData. For more information, please contact ISUReD@ilstu.edu. 
Return to Lagged Reserve Requirements

\title{
The Impact of the Return to Lagged Reserve Requirements on the Federal Funds Market
}

\author{
Vladimir Kotomin ${ }^{\mathrm{a}, *}$, Drew B. Winters ${ }^{\mathrm{b}, \dagger}$ \\ ${ }^{a}$ Department of Accounting \& Finance, College of Business, \\ University of Wisconsin - Eau Claire, Eau Claire, WI 54701 \\ ${ }^{\mathrm{b}}$ Department of Finance, Rawls College of Business, \\ Texas Tech University, Lubbock, TX 79409
}

JEL classification: G28/G18

Keywords: Reserve requirements, settlement Wednesday effects

* Tel.: 715-836-3535; fax: 715-836-3582; E-mail: Kotomin@uwec.edu
${ }^{\dagger}$ Corresponding author. Tel.: 806-742-3350; fax: 806-742-3197; E-mail address: drew.winters@ @tu.edu 


\begin{abstract}
We examine the impact on the settlement Wednesday effect in daily fed funds rates following the change from contemporaneous reserve requirements (CRR) to lagged reserve requirements (LRR). The Federal Reserve changed from CRR to LRR, in part, to make it easier for banks to settle their reserve accounts. Our hypothesis is that the switch to LRR will reduce the demand for reserves on settlement Wednesdays, thus reducing the settlement Wednesday effect in fed funds rates. Our empirical results provide strong support for our hypothesis.
\end{abstract}




\section{Introduction}

In July of 1998 the Federal Reserve Board bank settlement procedures switched from contemporaneous reserve requirements (CRR) back to lagged reserve requirements (LRR). Part of the purpose of this change is to make settlement with the Federal Reserve easier for depository institutions. We examine empirically whether this change made the settlement process easier for banks.

Specifically, we examine whether the switch to LRR reduces the welldocumented settlement Wednesday effects in the federal (fed) funds market. The pressure on depository institutions to settle with the Federal Reserve (Fed) has created a rate increase and volatility spike in the fed funds market on settlement day. The settlement effect is often referred to as the settlement Wednesday effect because depository institutions settle with the Federal Reserve bi-weekly on Wednesday. So, we examine whether the switch to LRR reduces the settlement Wednesday effect in fed funds rates because a reduction in the settlement Wednesday effects is consistent with less demand pressure for fed funds from banks attempting to settle with the Fed. We interpret any change in settlement procedures that reduces the demand for fed funds at settlement as making the settlement process easier for banks.

Since the establishment of the Federal Reserve System (Fed), member banks have been required to hold reserve assets in proportion to their deposit liabilities. ${ }^{1}$ Reserves must be held as deposits with the Fed or as vault cash. ${ }^{2}$ To ensure that banks regularly

\footnotetext{
${ }^{1}$ The Monetary Control Act of 1980 requires that most financial institutions accepting deposits in the U.S. hold reserves on deposit based on the reserve requirements defined in Regulation D of the Federal Code of Regulations (see, Cyree, Griffiths and Winters (2003)).

${ }^{2}$ Smaller banks maintain reserve balances in pass-through accounts with approved larger institutions.
} 
meet their reserve requirements, the Fed requires periodic reconciliation of each bank's reserves, which is referred to as settlement. In order to meet settlement requirements, institutions manage their reserve balances through trades in the federal (fed) funds market.

Periodic settlement occurs every two weeks on (settlement) Wednesday. The twoweek period is referred to as a reserve maintenance period and each reserve maintenance period consists of 14 calendar days, 10 of which are usually trading days. Actual reserves (deposits and vault cash) are counted for reserve maintenance purposes at the close of each day with balances on non-trading days set equal to the balances on the most recent trading day. At the end of each reserve maintenance period (on settlement Wednesday) the 14 daily actual reserve positions are accumulated and compared to the total required reserves for the reserve maintenance period. A bank has successfully settled if its total actual reserves are within the allowed range of total required reserves.

In February 1984 the Fed changed from a one-week reserve maintenance period to a two-week reserve maintenance period and at the same time switched from lagged reserve requirements (LRR) to contemporaneous reserve requirements (CRR) (see Saunders and Urich (1988)). Under CRR, the reserve computation period covers a twoweek period ending on the Monday before settlement Wednesday. ${ }^{3}$ Thus, under this system there is uncertainty about a bank's total required reserves until two days before settlement.

\footnotetext{
${ }^{3}$ For example, for the reserve maintenance period that started on August 14, 1997 and ended on August 27, 1997, the corresponding reserve computation period started on August 12, 1997 and ended on August 25, 1997.
} 
On March 26, 1998 the Federal Reserve Board voted to move from contemporaneous reserve requirements (CRR) back to lagged reserve requirements (LRR). This change went into effect with the reserve maintenance period beginning July 30, 1998. Under this lagged reserve system, the two-week reserve computation period begins 30 days before the beginning of the associated reserve maintenance period. The stated goal of the switch was to make it easier for banks to calculate their required reserve balances for each maintenance period and to increase the accuracy of information on aggregate required reserve balances, which was needed by the Open Market Trading Desk to carry out its operations.

The following is an excerpt from the Fed release: ${ }^{4}$

Providing a two-period lag for both required reserves and applied vault cash will allow the Federal Reserve, as well as depository institutions, to calculate the level of required reserve balances before the beginning of the maintenance period. It has become increasingly difficult to estimate the quantity of balances that depositories must hold at Reserve Banks to meet reserve requirements in the concurrent maintenance period, largely because of the implementation of retail sweep programs by many institutions. In addition to improving the ability of depository institutions and the Federal Reserve to estimate and project required reserve balances, the increased lag also should reduce the level of resources that must be devoted to these tasks. ${ }^{5}$

This paper examines how the switch back to LRR in 1998 affected the welldocumented settlement Wednesday rate increase and volatility spike in the fed funds market. Section 2 discusses the settlement rules for banks and describes a model of demand for reserves across the two-week reserve maintenance period to explain the persistence of the settlement Wednesday rate change and volatility effects. It also discusses how the switch to LRR from CRR would reduce uncertainty and what

\footnotetext{
${ }^{4}$ Regulation D, Docket No. R-0988 (available on the Federal Reserve Board of Governors' website).

${ }^{5}$ See Anderson and Rasche (2001) for a detailed description of retail sweep programs.
} 
implications it might have for the size of the settlement Wednesday effect. Section 3

extends section 2 to discuss the pervasive nature of settlement effects and how settlement effects can persist when a central bank manages interest rates. Section 4 describes the data and presents our methods. Section 5 presents empirical results. We find that the switch from CRR back to LRR eliminates both the identified settlement Wednesday rate increase and its associated settlement Wednesday volatility spike. We show that the widespread use of sweep accounts reduced the settlement Wednesday effect, but that this reduction in the settlement Wednesday effect is separate from the reduction in the settlement Wednesday effect from the change to LRR. We also show that the liquidity increase by the Fed associated with Y2K cannot explain the reduction in the settlement Wednesday effects following the switch to LRR. The last section concludes the paper.

\section{The Federal Funds Market and its Regularities}

The trading behavior of depository institutions in the fed funds markets is largely dependent on the settlement rules. The basic rules for settlement are:

1. Total required reserves are accumulated over a 14-day period called the reserve computation period. Required reserves are calculated for each of the 14 days in the two-week period with non-trading days assigned the preceding trading day's required reserves.

2. Total actual reserves are accumulated over a 14-day period called the reserve maintenance period. Actual reserves (deposits at the Fed and vault cash) are calculated for each of the 14 days in the two-week period with non-trading days assigned the preceding trading day's required reserves.

3. On settlement Wednesday (the last day in the maintenance period) a bank's total required reserves and its total actual reserves are compared to determine if a bank has managed its reserves within the settlement regulations. Thus, settlement Wednesday is the last day a bank can change its actual reserve position for settlement. 
4. It is difficult for banks to match total actual reserves and total required reserves in a given maintenance period. Thus, the carry-over provision of the settlement rules provides for small differences, described as allowable carryovers, to carry over into the next maintenance period. The maximum amount of the allowable carry-over for a bank is $4 \%$ of total required reserves or $\$ 50,000$, whichever is larger, and the amount can only be carried forward one maintenance period. If the carry-over is not offset in the next maintenance period, it is not allowed for carry-over into subsequent maintenance periods. Disallowed carryovers of excess reserves become permanently lost investment opportunities and disallowed carry-overs of reserve deficits are subject to monetary penalties as well as admonitions from the Fed. Differences (between total required and total actual reserves) outside the allowable carryover amount are disallowed in the maintenance period in which they occur and are subject to the same monetary penalties as disallowed carry-overs.

5. Thus, successful settlement (settlement without disallowed carry-overs) can be summarized by the following two criteria:

a. total actual reserves must be within (+/-) $4 \%$ of total required reserves or $\$ 50,000$, whichever is larger and

b. the depository institution oscillates between settling with excess reserves (total actual $>$ total required) and with short reserves (total actual $<$ total required). ${ }^{6}$

In addition to the settlement rules, it is important to note that the Fed does not pay interest on actual reserves on deposit at the Fed nor does it charge interest to banks that run reserve deficits on non-settlement days. ${ }^{7}$ Thus, excess reserves are lost investment opportunities for banks and reserve deficits are interest-free loans for banks. In addition, excess reserves become permanently lost investment opportunities when the accumulated excesses in a maintenance period exceed a bank's work-off rate (see, Spindt and Hoffmeister (1988)), while reserve deficits are limited only by a bank's fed funds borrowing limits on settlement Wednesdays. Thus, Griffiths and Winters (1995) suggest that the settlement rules create strong incentives to (1) lend (run a daily reserve deficit)

\footnotetext{
6 If an institution settles with total actual reserves equal to total required reserves, then the institution has the choice to settle with excess reserves or short reserves in the next reserve maintenance period.

${ }^{7}$ We note that the Fed does not allow banks to overdraw their accounts overnight without penalty. Also, the Fed began limiting daylight overdrafts in 1986 and in 1994 the Fed began imposing penalties on banks with daylight overdrafts in their reserve accounts (see, Hancock and Wilcox (1996)).
} 
across the maintenance period, (2) lend on Fridays, (3) borrow on settlement Wednesday to accumulate the necessary reserves for settlement.

Most previous research has inferred demand for reserves by examining the daily rate changes and volatility in the fed funds market. ${ }^{8}$ Clouse and Dow (2002) take a different approach and use numerical methods to model the demand for excess reserves at a representative bank. Since the demand for reserves creates the settlement Wednesday rate change and volatility effect, we use the results from the Clouse and Dow model to frame our expectations for the impact of the switch back to LRR on the settlement Wednesday effects.

Clouse and Dow (2002) assume that banks minimize the discounted cost of maintaining reserves over an infinite horizon, which requires them to use a dynamic programming approach to solve for the daily demand for reserves. Clouse and Dow state:

(T)his structure is naturally modeled as an infinite horizon dynamic programming problem in which a bank chooses a sequence of reserves over the 10 business days of the maintenance period, given a predetermined value of carry-in, so as to minimize the expected current period cost of reserve maintenance along with the discounted expected costs in all future maintenance periods. The expected cost of reserve management within a given maintenance period includes the opportunity cost of holding non-interest bearing reserves plus the expected costs associated with potential overnight overdrafts and reserve requirement deficiencies.

Using this model, Clouse and Dow determine the optimal pattern for holding reserves across the days of the maintenance period. They find three notable features for daily reserve demand, which are:

\footnotetext{
${ }^{8}$ For example, see Spindt and Hoffmeister (1988), Griffiths and Winters (1995), Hamilton (1996), Griffiths and Winters (1997), and Cyree and Winters (2001a).
} 
1. the desired level of reserves is significantly lower on Fridays,

2. there is a small upward trend in expected demand for reserves over the maintenance period, and

3. there is a pronounced upward spike in demand on the last day of the maintenance period.

Clouse and Dow note that the pattern in daily demand for reserve across the reserve maintenance period is consistent with the pattern of daily demand for reserves implied in the previous work testing daily changes in fed funds rates. The empirical results on daily rate changes find that rates decline on Fridays and increase on settlement Wednesday and the volatility generally increases across the reserve maintenance period with settlement Wednesdays having the largest daily volatility.

Clouse and Dow perform sensitivity analysis on the results from their model. In one test, they change the volatility in reserve shocks and find that increases in uncertainty shifts reserve demand toward the last day of the maintenance period. In other words, an increase in uncertainty increases the demand for reserves on settlement Wednesday which, in turn, would increase the settlement Wednesday effect in rate changes and volatility. They also find that a reduction in uncertainty reduces the demand for reserve on settlement Wednesday.

The switch from CRR to LRR would reduce uncertainty about a bank's total required reserves for a reserve maintenance period. Under the CRR system in place from February 1984 through July 1998 the two-week reserve computation period overlaps the first 12 days the two-week reserve maintenance period. Thus, over the first 12 days of the reserve maintenance period a bank only has an estimate of its total required reserves for the period because required reserves are being calculated through the Monday 
immediately before settlement Wednesday. Accordingly, the bank uses a moving estimate throughout the majority of the period and has only two days to adjust once the target amount of total required reserves is known. The uncertainty of the total required reserves can be eliminated by switching to a computation period that ends before the beginning of the associated reserve maintenance period. Under the new system of LRR the Fed chose to have the computation period begin 30 days before the maintenance period. The goal is to have a bank's total required reserves known at the beginning of each maintenance period, yet keep the computation period close enough to the beginning of the maintenance period to minimize any effect from seasonal changes in deposits and vault cash. The elimination of the uncertainty in the amount of total required reserves makes it easier for banks to manage their reserve accounts for settlement.

The switch from CRR to LRR allows the banks to know with certainty their total required reserves at the beginning of each two-week maintenance period instead of having to wait until only two days before the end of the maintenance period to know their total required reserves with certainty for that period. Thus, the move back to LRR eliminates one source of uncertainty in the reserve management process. Clouse and Dow (2002) suggest that a reduction in uncertainty reduces the demand for reserves on settlement Wednesday. ${ }^{9}$ Accordingly, we hypothesize that the switch from CRR to LRR should reduce the settlement Wednesday effect in daily rate changes and daily volatility in fed funds rates by reducing the demand for reserves on settlement Wednesday.

\footnotetext{
${ }^{9}$ We note that Clouse and Dow (2002) develop their model under LRR and that the uncertainty that they discuss is uncertainty due to bank customer transactions. However, under CRR, uncertainty about customer transactions translates into uncertainty about required reserves over the first 12 days of the maintenance period. Thus, their results generalize to reduction in uncertainty for reserve account management under LRR. Having a known target throughout a reserve maintenance period is clearly a reduction in uncertainty for reserve account management purposes.
} 
Griffiths and Winters (1995) and Clouse and Dow (2002) suggest that Fridays are different from the other days in the maintenance period and empirical work shows that fed funds rates decline on Fridays. Accordingly, testing for changes on Fridays around the switch would be reasonable. However, Cyree, Griffiths and Winters (2003) note that explanations exist outside of the settlement process for why rates should decline on Fridays. They also state that the settlement Wednesday effect is unique to the settlement process. Accordingly, we focus our discussion of the impact from switching from CRR to LRR on settlement Wednesday and include Fridays in our model as control variables (see equations (1) and (2) in section 4.2).

\section{Further Discussion of Settlement Effects and the Caveat of Fed Market Intervention}

As we mentioned above, settlement Wednesday rate increases and volatility spikes are well-documented in the US fed funds market. ${ }^{10}$ However, it is worth noting that this effect is not limited to the US banking system. Bartolini and Prati (2005) document that an increase in volatility on settlement day is common across countries that use periodic reserve requirements to stabilize interbank rates. ${ }^{11}$ Thus, settlement day effects are a common feature of banking systems with positive reserve requirements and periodic settlement.

Bartolini and Prati (2005) note that some of the literature on settlement effects focuses only on the demand side of the market. However, focusing only on the demand side of the market ignores supply side effects from central bank market intervention.

\footnotetext{
${ }^{10}$ For example, see Spindt and Hoffmeister (1988), Griffiths and Winters (1995), Hamilton (1996), Griffiths and Winters (1997), and Cyree and Winters (2001a).

${ }^{11}$ They find that volatility increases on settlement day in Japan, Germany, France, Italy and the Euro-Zone.
} 
Perez-Quiros and Mendizabal (2005) describe central bank invention as an attempt to keep market rates around an official rate with the official rate often being referred to as a target rate.

During our sample period the Fed is managing market interest rates around a policy target rate (see, Thornton (2004)). Thus, with the Fed managing interest rates around a policy target an important question is why do we observe predictable patterns in the fed funds rate driven by bank demand for fed funds?

Feinman (1993) notes that the Fed is unlikely to make a strong move against deviations in the fed funds rate from the target rate on Fridays and settlement Wednesdays. This is because these deviations tend to be self-correcting. Bartolini, Bertola, and Prati (2001) find evidence that the Fed is willing to tolerate a spread in rates within a maintenance period of 15 basis points. They state that

“(T)his realistically captures the Fed's reluctance to provide liquidity elastically at a fixed target rate, and its preference for enforcing a small corridor of rates, the width of which reflects its tolerance for day-to-day expected interest rate fluctuations."

Griffiths and Winters (1995) find that the average daily spread between the high and low fed funds rate is: between 11 and 15 basis points over the first eight trading days of the maintenance period, is 25 basis on the day before settlement, and is 59 basis points on settlement Wednesdays.

The bottom line from the discussion in this section is that the Fed does intervene to manage interest rates, but it does not micro-manage interest rates to the point of eliminating rate change and volatility patterns driven by bank demand for reserves for the settlement process. Accordingly, we will examine daily fed funds rate changes at 
settlement for changes in bank demand pressures from the switch to LRR while controlling for Fed daily market intervention (see, equations (1) and (2) in section 4.2).

\section{Data and Methods}

\subsection{Data and Summary Statistics}

On a daily basis there are two different fed funds rates available: (1) average and (2) marginal. We collected the closing marginal fed funds rate from the daily logs of the International Money Market (IMM) Division of the Chicago Mercantile Exchange, which is the closing bid side broker quote. The daily average fed funds rate is called the effective fed funds rate. This rate is a volume-weighted average of the rates on the fed funds transactions for the day. The daily effective fed funds rate is calculated by the Federal Reserve Bank of New York and was collected from the Federal Reserve Board of Governors' website. In addition, we collected the daily closing yield on three-month Treasury bills (T-bill) from the IMM daily logs. We use T-bill yields to proxy for the general level of short-term interest rates.

Our primary analysis covers the period from August 1, 1996 to July 26, 2000. This period is divided into two subperiods: two years ( 52 reserve maintenance periods) before and two years after the change to LRR became effective. The first two-week reserve-maintenance period under LRR started on July 30, 1998. The decision to limit the span of the sample is not arbitrary. In this paper we attempt to study market participants' reaction to a regulatory change by inferring their trading behavior from the pattern in daily rate changes and volatility. To infer the reaction of market participants to the regulatory change from the pattern in rate changes and volatility, we must hold 
everything else constant. Limiting the sample to two years of data on either side of the change to LRR is done to allow all the data to be drawn from a more or less similar interest rate and general economic environment. We include 52 reserve maintenance periods in each subperiod to provide enough observations for our statistical tests. ${ }^{12}$

Clearly, we could increase the sample size because data are available after 2000. However, as Figure 1 shows, if we extend the end of the sample period, we move into the beginning of a different interest rate environment where rates decline over an extended period of time. A period of declining rates is consistent with the supply of funds exceeding the demand for funds, ceteris paribus. Clouse and Dow (2002) show that demand increases on settlement Wednesday which results in rates increasing. Therefore extending the sample into a prolonged period of declining interest rates would bias the sample towards supporting our hypothesis. Accordingly, we feel that limiting our sample following the event to exclude the prolonged period of declining interest rates is a reasonable and appropriate research design.

Table 1 contains descriptive statistics on the interest rates data over the two subperiods. The average T-bill yield was 14 basis points lower during the LRR subperiod than during the CRR subperiod, which reflects a slight decline in the general level of interest rates and suggests a need to control for the general level of short-term interest rates in our analysis. Also, T-bill yields are significantly more volatile in the later subperiod, which suggests that increased volatility in the market biases against finding a reduction in settlement Wednesday volatility under LRR.

\footnotetext{
${ }^{12}$ We have also conducted our analysis using one year of data (26 reserve maintenance periods) and the results are qualitatively similar. We report the results using two years because we prefer the larger sample size for statistical reasons.
} 
We distinguish between effective and closing fed funds rates because closing rates may not represent normal (average) trading behavior in the fed funds market as trading pressure increases toward the end of the day. Therefore, closing rates may result from end-of-the-day squeezes at a particular bank. Consistent with increased end-of-theday trading pressures, we find that closing rates exhibit higher variability than average rates under both regimes, which is in line with the findings of Griffiths and Winters (1995) and Cyree and Winters (2001a and 2001b) that volatility rises at the end of the day.

Table 2 contains descriptive statistics for closing rates for each day of the reserve maintenance period and provides preliminary evidence of a reduction in the settlement Wednesday effect concurrent with the switch to LRR. Specifically, the well-documented settlement Wednesday increase in the fed funds rate remains strong under CRR in our sample period (16 basis point increase), but disappears after the switch to LRR ( 2 basis point decrease). In addition, the standard deviations show similar results with a 17 basis point increase on settlement Wednesday under CRR, but only a 6 basis point increase on settlement Wednesday under LRR.

Figure 2 plots the daily means from Table 2. Griffiths and Winters (1995) suggest that lending pressures across the maintenance period should cause a decline in rates across the maintenance period until settlement Wednesday. Empirical evidence generally supports the decline in rates across the maintenance period. ${ }^{13}$ Clouse and Dow (2002) suggest that a decrease in uncertainty decreases demand for reserves across all days in the maintenance period. Figure 2 shows that daily average rates are lower

\footnotetext{
${ }^{13}$ See, for example, Griffiths and Winters (1995), Hamilton (1996) and Lee (2003).
} 
during the LRR period than during the CRR which is consistent with less demand for reserves. However, Table 1 reports that T-bill yields, which are not subject to settlement rules, are 14 basis points lower during the LRR period than the CRR period suggesting the lower daily averages under LRR in Figure 2 may simply be the result of lower levels of interest rates in general. We also estimate the slope of a linear regression for the two plot lines in Figure 2. Over the first nine days of the maintenance period the slopes for CRR and LRR are almost identical $($ CRR slope $=-0.0079$ and LRR slope $=-0.0075)$ while slopes including settlement Wednesday are an order of magnitude different (CRR slope $=-0.0013$ and LRR slope $=-0.0132$ ). These results suggest a change in the rate behavior on settlement Wednesday with the switch from CRR to LRR.

The evidence from Table 2 suggests some fundamental changes in the rate pressures in the fed funds market after the switch to LRR. However, these results must be viewed as preliminary because fed funds rate changes have identified time series characteristics that need to be controlled for in a GARCH model (see Hamilton (1996) and Cyree and Winters (2001a)), which we do in obtaining the results reported in the remainder of the paper. 


\subsection{Methods}

We estimate the following GARCH model for the analysis of the changes in the fed funds rates (both closing and effective) and their variances:

$$
\begin{aligned}
F F_{t}-F F_{t-1} & =\alpha_{0}+\alpha_{1} \text { LagFF }+\alpha_{2} \Delta T B_{t}+\alpha_{3} 1 \text { stThurs }+\alpha_{4} 1 \text { stFri }+\alpha_{5} 2 \text { ndFri } \\
& +\alpha_{6} \text { SetWed }+\alpha_{7} \text { Qend }+\alpha_{8} \text { Add }+\alpha_{9} \text { Drain }+\alpha_{10} \text { Switch } \\
& +\alpha_{2}^{\prime} T B_{t} \text { Switch }+\alpha_{3}^{\prime} 1 \text { stThursSwitch }+\alpha_{4}^{\prime} 1 \text { stFriSwitch } \\
& +\alpha_{5}^{\prime} 2 \text { stFriSwitch }+\alpha_{6}^{\prime} \text { SetWedSwitch }+\alpha_{7}^{\prime} \text { QendSwitch } \\
& +\alpha_{8}^{\prime} \text { AddSwitch }+\alpha_{9}^{\prime} \text { DrainSwitch }+\varepsilon_{t}
\end{aligned}
$$

\begin{tabular}{|c|c|}
\hline$F_{\mathrm{t}}=$ & $\begin{array}{l}\text { fed funds rate for day } t \text {. We employ the change in the fed funds rate as the } \\
\text { dependent variable, }{ }^{4}\end{array}$ \\
\hline $\operatorname{Lag} F F=$ & The previous day's change in the fed funds rate $\left(\mathrm{FF}_{\mathrm{t}-1}-\mathrm{FF}_{\mathrm{t}-2}\right)$, \\
\hline$\Delta T B_{t}=$ & The change in the three-month T-bill yield $\left(\mathrm{TB}_{\mathrm{t}}-\mathrm{TB}_{\mathrm{t}-1}\right)$, \\
\hline 1stThurs $=$ & $\begin{array}{l}1 \text { on the first Thursday of each reserve maintenance period and } 0 \\
\text { otherwise, }\end{array}$ \\
\hline $1 s t F r i=$ & 1 on the first Friday of each reserve maintenance period and 0 otherwise, \\
\hline $2 s t F r i=$ & $\begin{array}{l}1 \text { on the second Friday of each reserve maintenance period and } 0 \\
\text { otherwise, }\end{array}$ \\
\hline SetWed $=$ & 1 on the settlement Wednesday and 0 otherwise, \\
\hline Qend $=$ & 1 on the last trading day of each quarter and 0 on all other days, \\
\hline$A d d=$ & 1 on the days the Federal Reserve adds temporary reserves, ${ }^{15}$ \\
\hline Drain $=$ & 1 on the days the Federal Reserve drains temporary reserves, ${ }^{16}$ \\
\hline Switch $=$ & 0 under CRR and 1 under LRR, and \\
\hline & is the error term, which is assumed to be normally distributed. \\
\hline
\end{tabular}

where:

\footnotetext{
${ }^{14}$ Alternative specifications of the dependent variable do not qualitatively change the results.

${ }^{15} A d d$ and Drain are control variables that we use to recognize the Federal Reserve's influence on shortterm interests. We expect that the Fed will add reserves when there is upward pressure on interest rates that moves market rates away from the policy target rates and drain reserves when there is downward pressure on interest rates that moves market rates away from the policy target rates. However, since the Fed is not constrained to act in a particular manner, we do not have any expectations for the sign of the parameter estimates on these two independent variables and only include these variables to recognize the Fed's daily influence on the fed funds rate. We note that removing these variables from the model does not change the interpretation of our results. We collect the daily temporary open market operations from the daily logs of the IMM Division of the Chicago Mercantile Exchange.

${ }^{16}$ We do not control for target rate changes. Target rate changes are associated with changing the level of rates, but are unlikely to alter the daily rate change behavior across settlement periods so we do not include target rate changes in our GARCH model. However, we do note that the target rate changed once during the first sub-period of our sample (CRR) and nine times during the second sub-period of our sample (LRR).
} 
The conditional variance equation is specified as follows:

$$
\begin{aligned}
\sigma_{t}^{2} & =b_{0}+b_{1} \sigma_{t-1}^{2}+b_{2} \varepsilon_{t-1}^{2}+b_{3} \varepsilon_{t-1}^{2} I_{t}+c_{1} \Delta T B_{t}+c_{2} 1 \text { stThurs }+c_{3} 1 \text { stFri } \\
& +c_{4} 2 n d F r i+c_{5} \text { SetWed }+c_{6} \text { Qend }+c_{7} \text { Add }+c_{8} \text { Drain }+c_{9} \text { Switch } \\
& +c_{1}^{\prime} T B_{t} \text { Switch }+c_{2}^{\prime} 1 \text { stTrursSwitch }+c_{3}^{\prime} 1 \text { stFriSwitch }+c_{4}^{\prime} 2 n d F r i S w i t c h \\
& +c_{5}^{\prime} \text { SetWedSwitch }+c_{6}^{\prime} \text { QendSwitch }+c_{7}^{\prime} \text { AddSwitch }+c_{8}^{\prime} \text { DrainSwitch }
\end{aligned}
$$

where:

$I_{t}=\quad$ is an indicator variable equal to 1 if the lagged error $\left(\varepsilon_{\mathrm{t}-1}\right)$ is negative and 0 otherwise.

The change in daily T-bill yields controls for changes in the general level of shortterm interest rates. The dummy variables for Fridays, settlement Wednesday, and quarterends are suggested by Cyree, Griffiths, and Winters (2003). Clouse and Dow (2002) suggest that the demand for reserves on the first day of a reserve maintenance period is different because of the carry-in provision. Accordingly, we include a dummy variable for the first day of the reserve maintenance period (the first Thursday) in our model. The Switch variable controls for the change from CRR $($ Switch $=0)$ to LRR $($ Switch $=1)$ and allows for the use of interactive variables to test for changes in the rate change and volatility effects in fed funds rates.

Spindt and Hoffmeister (1988) predicted and empirically confirmed that daily variance increases over the reserve maintenance period and is highest on settlement Wednesday. This implies a conditional variance, and Hamilton (1996) uses a GARCH model to specify the conditional variance for daily fed funds rate changes. Cyree and Winters (2001a) use the asymmetric GARCH model proposed by Glosten, Jagannathan, and Runkle (GJR, 1993) to model the conditional variance. The choice of the GJR model accommodates the asymmetry between excess reserves (lost investment opportunities) and reserve shortages (investments using an interest-free loan from the Fed) in the 
conditional variance equation (as discussed in Griffiths and Winters (1995) and Cyree and Winters (2001a)). ${ }^{17}$ We include the same set of dummy variables in the conditional variance equation as in the mean equation. All of the dummy-variable regressors that enter the conditional variance equation are contemporaneous with the variance. This is justified because daily variances are created by settlement rules and influenced by the day of the reserve maintenance period. The inclusion of the quarter-end dummy is supported by Hamilton (1996) who notes that there are significant quarter-end conditioning effects on the daily variance.

\section{Results}

\subsection{GARCH model results}

The main goal of our study is to determine if and how the dynamics of the fed funds daily rate behavior changed after the switch to LRR. Specifically, we focus on changes in the settlement Wednesday effect. To achieve our goal we estimate our GARCH model on daily closing and daily effective fed funds rates across our sample period of August 1, 1996 to July 26, 2000. For comparison we also estimate a GARCH model without the Switch and interactive variables separately for the CRR and LRR subsamples. We report the results for closing fed funds rates in Table 3 and the results

\footnotetext{
${ }^{17}$ On any given day of the reserve maintenance period banks either have excess reserves (actual reserves > required reserves) or short reserves (actual reserves < required reserves). Excess reserves are an opportunity cost for the bank because it means the bank missed on an opportunity to lend (invest) the excess. Short reserves represent lending (investing) fed funds using an interest-free loan from the Federal Reserve. If banks have excess reserves, they will try to lend the excess amount, which will likely reduce the fed funds rate. Along with the increased variance, the actual rate is likely to be below the rate predicted by the model (so the error term is negative). The variance of the fed funds rate is likely to be higher on the days when banks have excess reserves since banks strive to avoid large excess reserve balances. Thus, a clear asymmetry exists, which we believe makes the dummy variable definition for the asymmetric term in the GJR model appropriate.
} 
for effective fed funds rates in Table 4 . The first set of results in Tables 3 and 4 are from the full model estimated on the entire sample. The second set of results is from the CRR subsample with the third set of results from the LRR subsample. The implications of the empirical results are the same whether we focus on the full sample or the subsamples. Accordingly, we focus our discussion on the full model estimated across the entire sample and provide the other results for comparison.

Starting with the mean equation results from daily closing fed funds rates in Table 3 , we find that the parameter estimate for the lag of the daily change in rates is negative and significant at better than the $1 \%$ level. The negative sign on the parameter estimate is consistent with the pattern of daily demand for reserve in the Clouse and Dow (2002) model and consistent with the daily pattern in rate changes reported in studies on daily fed funds rate changes. ${ }^{18}$ The other control variables that are significant are the quarterend variable (positive and significant at better than the 5\% level) and the first Friday variable (negative and significant at better than the $5 \%$ level).

The point of the switch to LRR from CRR is to make it easier for banks to settle, which we suggest should reduce the demand for reserves on settlement Wednesday and thus reduce the rate increase and volatility increase in the fed funds rate on settlement Wednesday. The parameter estimate of the settlement Wednesday variable is positive and significant at better than the $1 \%$ level, while the interactive settlement Wednesday variable is negative and significant at better than the $1 \%$ level. This combination of results suggests that rates increase significantly on settlement Wednesday during the period with CRR and that the settlement Wednesday effect during LRR is significantly

\footnotetext{
${ }^{18}$ For example, see, Griffiths and Winters (1995), Hamilton (1996), Cyree and Winters (2001a), and Lee (2003).
} 
less than during CRR. In fact, the results from the LRR subsample suggest that after the switch to LRR there is no longer a significant rate change on settlement Wednesday. These results support the hypothesis that the switch to LRR would reduce the settlement Wednesday rate increase.

The results from the variance equation find significant parameter estimates for the $\mathrm{ARCH}, \mathrm{GARCH}$, and asymmetric variables suggesting that the fed funds rate change variance is conditional, as expected. The parameter estimate for Switch is negative and significant at better than the 5\% level suggesting that, on average, volatility in daily rate changes declined under LRR. The parameter estimate for the settlement Wednesday variable is positive and significant at better than the $1 \%$ level while the settlement Wednesday interactive variable is negative and significant at better than the $5 \%$ level. These results suggest a significant increase in daily volatility on settlement Wednesday under CRR with significantly less daily volatility on settlement Wednesday under LRR. The results for the LRR subperiod suggest that the decline in settlement Wednesday volatility under LRR is sufficient to make settlement Wednesday volatility not significantly different from volatility on the days not covered by the dummy variables. This result provides further support for our hypothesis that the switch to LRR would reduce the settlement Wednesday effect.

The results in Table 3 come from daily closing fed funds rates and thus reflect the trading behavior of a bank at the end of the day. Since the behavior of one bank at the end of the day may not reflect average behavior, we re-estimate our GARCH model on daily effective fed funds rates, which represent the average rates of each day's fed funds transactions. These results are reported in Table 4. 
The mean equation results using daily effective fed funds rates are similar to the results using the daily closing rates. In particular, we find that rates increase significantly on settlement Wednesday under CRR, but there is not a significant increase under LRR. With the effective rate we do not find that volatility increases on settlement Wednesday under CRR, but we do find the settlement Wednesday volatility is significantly lower under LRR than under CRR. ${ }^{19}$

\subsection{Robustness Checks of Alternative Explanations}

One possible alternative explanation for the disappearance of the settlement Wednesday rate increase is the introduction of sweep accounts. Anderson and Rasche (2001) note the Fed began allowing sweep accounts in January 1994 and that by December 1999 the widespread use of sweep accounts had reduced the total required reserves for many banks below the vault cash and Fed deposits necessary for day-to-day business operations. Having total required reserves below the cash needs for day-to-day operations for many banks could reduce or eliminate the settlement Wednesday rate increase because it would force banks to lend on settlement Wednesdays to settle instead of borrowing to settle as suggested by the Clouse and Dow (2002) model and the associated empirical results.

A closer look at the results in Anderson and Rasche shows that the transition from reservable deposits to sweep accounts was almost complete by January 1997. To provide independent verification of the timing of this shift in reserves, we collected two monthly reserve data series in \$billion from the web site of the Federal Reserve Bank of St. Louis

\footnotetext{
${ }^{19}$ Being a weighted-average rate, the effective fed funds rate is bound to have lower volatility than the closing daily rate.
} 
(http://research.stlouisfed.org/fred2/). The two data series are described by the Fed as:

(1) excess reserves of depository institutions and (2) excess reserves plus required clearing balance contracts of depository institutions. The reason for collecting the second data series is that with the use of sweep accounts the required reserves of many banks fell below the amount of reserve deposits the banks needed for daily clearing operations, so these banks entered into clearing balance contracts to hold extra deposits in their Fed accounts for clearing purposes.

Figure 3 plots monthly excess reserves and shows that from January 1994 until January 1997 excess reserves averaged about $\$ 1$ billion, and from January 1997 through July 2000 excess reserve were generally around $\$ 1.2$ billion to $\$ 1.3$ billion. Figure 4 plots monthly excess reserves plus clearing balances and also shows a distinct break in the data series at January 1997. Both plots support our conclusion from the Anderson and Rasche (2001) results that the impact of sweep accounts on reserves had taken place by January 1997. Accordingly, we re-estimate our GARCH results removing all the observations before January 1997 (August 1, 1996 through December 31, 1996). The results from this re-estimation are qualitatively similar to those reported in Table 3, so they are not presented in the interest of brevity. These results suggest that the implementation of sweep accounts is not the reason for the elimination of the settlement Wednesday effect in the LRR part of our sample period.

To show the effect of sweep accounts on daily fed funds rate behavior, we reestimate our GARCH model for the period from July 7, 1994 through July 29, 1998 (the last day under CRR) defining the shift variable to be 0 before January 1, 1997 and 1 from January 1, 1997 through July 29, 1998. All other variables are defined as in Equations 1 
and 2. The results from this model estimation are presented in Table 5 with the first set reporting results for daily closing fed funds rates and the second set reporting results for daily effective fed funds rates. Both sets of results show that the widespread use of sweep accounts dramatically reduced the settlement Wednesday rate increase, but they also indicate that, from January 1997 through July of 1998, a settlement Wednesday rate increase of between five and ten basis points still exists. The volatility spike in the closing rate on settlement Wednesday was not affected by the implementation of sweep accounts. Combined with our results on the switch to LRR, this suggests that sweep accounts reduced the settlement Wednesday effect in fed funds rates and that the switch to LRR further reduced the effect on settlement Wednesday to the point where the rate changes and volatility increase are not statistically different from zero.

Finally, both Figures 3 and 4 show a spike in excess reserves at January 2000. This spike is from the increased liquidity provided by the Fed in conjunction with Y2K. This increase in reserves may have reduced settlement Wednesday borrowing around Y2K and therefore could have been the reason why we did not find a settlement Wednesday effect with the switch to LRR. Accordingly, we re-estimate our original model with control for Y2K in the form of a dummy variable that covers December 1999 and January 2000. The results from this estimation are qualitatively similar to those reported in Table 3 (so not reported for brevity), which suggests that the Fed's liquidity increase for $\mathrm{Y} 2 \mathrm{~K}$ is not the reason for the elimination of the settlement Wednesday effect with the switch to LRR.

\section{Conclusion}


We analyze the effect of the 1998 Federal Reserve decision to provide a 30-day lag between the beginning of a computation period for required reserves of depository institutions and the beginning of the associated reserve maintenance period. This allows depositories to calculate the level of required reserves before the beginning of the maintenance period. The switch from contemporaneous (CRR) to lagged reserve requirements (LRR) was implemented to achieve the goal of facilitating settlement with the Fed for banks. The goal was apparently achieved, which is evidenced by the smoother behavior of both the effective and closing fed funds rates throughout the reserve maintenance period in terms of both the level and volatility. Specifically, the welldocumented settlement Wednesday increase in the fed funds rate has been eliminated from our data after the switch to lagged reserve requirements. In addition, the associated settlement Wednesday spike in the volatility of the fed funds rate has also been eliminated from the data after the change took place.

\section{Acknowledgements}

The authors thank the two anonymous reviewers for the journal for the thoughtful comments which improved the paper. 


\section{Return to Lagged Reserve Requirements}

\section{References}

Anderson, R., \& Rasche, R. (2001). Retail sweep programs and bank reserves, 1994-1999. Federal Reserve Bank of St. Louis Review 83, 57-72.

Bartolini, L., \& Prati, A. (2005). Cross-country differences in monetary policy execution and money market rates' volatility. European Economic Review forthcoming.

Bartolini, L., Bertola, G., \& Prati, A. (2002). Day-to-day monetary policy and the volatility of the federal funds interest rate. Journal of Money, Credit, and Banking 34, 137-159.

Bartolini, L., Bertola, G., \& Prati, A. (2001). Banks' reserve management, transaction costs, and the timing of Federal Reserve intervention. Journal of Banking and Finance 25, 1287-1317.

Clouse, J., \& Dow, J. (2002). A computational model of banks' optimal reserve management policy. Journal of Economic Dynamics and Control 26, 1787-1814.

Cyree, K., Griffiths, M., \& Winters, D. (2003). On the pervasive effects of Federal Reserve settlement regulations. Federal Reserve Bank of St. Louis Review 85, 27-46.

Cyree, K., \& Winters, D. (2001a). Analysis of the federal funds rate changes and variance patterns. Journal of Financial Research 24, 403-418.

Cyree, K., \& Winters, D. (2001b). An intraday examination of the federal funds market: implications for the theories of the reverse-J pattern. Journal of Business 74, 535-556.

Feinman, J. (1993). Estimating the open market desk's daily reaction function. Journal of Money, Credit, and Banking 25, 231-247.

Glosten, L., Jagannathan, R., \& Runkle, D. (1993). On the relation between the expected value and the volatility of the nominal excess return on stocks. Journal of Finance 48, 1779-1801.

Griffith, M., \& Winters, D. (1995). Day-of-the-week effects in federal funds rates: further empirical findings. Journal of Banking and Finance 19, 1265-1284.

Griffith, M., \& Winters, D. (1997). The effect of Federal Reserve accounting rules on the equilibrium level of overnight repo rates. Journal of Business Finance \& Accounting 24, 815-832.

Hamilton, J. (1996). The daily market for federal funds. Journal of Political Economy 104, 26-56.

Hancock, D., \& Wilcox, J. (1996). Intraday management of bank reserves: The effects of caps and fees on daylight overdrafts. Journal of Money, Credit, and Banking 28, 870-908.

Lee, Y. (2003). The federal funds market and the overnight Eurodollar market. Journal of Banking and Finance 27, 749-771.

Perez-Quiros, G., \& Mendizabal, H. (2005). The daily market for funds in Europe: What has changed with the EMU?. Journal of Money, Credit and Banking forthcoming.

Saunders, A., \& Urich, T. (1988). The effects of shifts in monetary policy and reserve 


\section{Return to Lagged Reserve Requirements}

accounting regimes on bank reserve management behavior in the federal funds market. Journal of Banking and Finance 12, 523-535.

Spindt, P., \& Hoffmeister, J. (1988). The micromechanics of the federal funds market: implications for day-of-the-week effects in funds rate variability. Journal of Financial and Quantitative Analysis 23, 401-416.

Thornton, D. (2004). When did the FOMC begin targeting the federal funds rate? What the verbatim transcripts tell us. Federal Reserve Bank of St Louis working paper series (\#2004-015A). 


\section{Table 1}

Descriptive statistics for fed funds rates and three-month Treasury bill yields for the periods August 1, 1996 - July 29, 1998 and July 30, 1998 - July 26, 2000

\begin{tabular}{|c|c|c|c|c|c|}
\hline \multicolumn{6}{|c|}{ Panel A: Descriptive Statistics for CRR (August 1, 1996 to July 29, 1998) } \\
\hline & $\mathrm{N}$ & Mean & St. Dev. & Low & High \\
\hline \multicolumn{6}{|l|}{ fed funds rates: } \\
\hline Effective & 498 & 5.46 & 0.25 & 4.63 & 7.07 \\
\hline Close & 498 & 5.46 & 0.32 & 4.5 & 8.00 \\
\hline Treasury bill yields & 498 & 5.03 & 0.09 & 4.75 & 5.34 \\
\hline \multicolumn{6}{|c|}{ Panel B: Descriptive Statistics for LRR (July 30, 1998 to July 26, 2000) } \\
\hline & $\mathrm{N}$ & Mean & St. Dev. & Low & High \\
\hline \multicolumn{6}{|l|}{ fed funds rates: } \\
\hline Effective & 500 & 5.33 & 0.59 & 3.99 & 7.03 \\
\hline Close & 500 & 5.31 & 0.63 & 3.50 & 7.13 \\
\hline Treasury bill yields & 500 & 4.89 & 0.56 & 3.56 & 6.02 \\
\hline
\end{tabular}


Return to Lagged Reserve Requirements

Table 2

Closing Rates by Day of the Maintenance Period

\begin{tabular}{ccccccc}
\hline \multicolumn{7}{c}{ Panel A. CRR (August 1, 1996 to July 29, 1998) } \\
\hline Day & Mean & Median & Minimum & Maximum & Range & St.Dev. \\
\hline 1st Thur & 5.542 & 5.500 & 5.125 & 8.000 & 2.875 & 0.400 \\
1st Fri & 5.395 & 5.375 & 4.750 & 6.500 & 1.750 & 0.244 \\
1st Mon & 5.494 & 5.438 & 5.125 & 6.250 & 1.125 & 0.221 \\
1st Tues & 5.463 & 5.438 & 4.750 & 7.000 & 2.250 & 0.394 \\
1st Wed & 5.407 & 5.438 & 4.875 & 6.750 & 1.875 & 0.283 \\
2nd Thur & 5.471 & 5.500 & 5.000 & 6.438 & 1.438 & 0.257 \\
2nd Fri & 5.402 & 5.375 & 5.000 & 5.813 & 0.813 & 0.199 \\
2nd Mon & 5.521 & 5.500 & 5.000 & 6.500 & 1.500 & 0.310 \\
2nd Tues & 5.373 & 5.438 & 5.000 & 6.750 & 1.750 & 0.290 \\
2nd Wed & 5.534 & 5.500 & 4.500 & 7.000 & 2.500 & 0.463 \\
\hline
\end{tabular}

Panel B. LRR (July 30, 1998 to July 26, 2000)

\begin{tabular}{ccccccc}
\hline Day & Mean & Median & Minimum & Maximum & Range & St.Dev. \\
\hline 1st Thur & 5.395 & 5.313 & 4.000 & 6.875 & 2.875 & 0.624 \\
1st Fri & 5.254 & 5.156 & 4.250 & 7.125 & 2.875 & 0.610 \\
1st Mon & 5.454 & 5.438 & 4.500 & 7.125 & 2.625 & 0.615 \\
1st Tues & 5.287 & 5.250 & 4.000 & 6.438 & 2.438 & 0.599 \\
1st Wed & 5.299 & 5.313 & 3.500 & 6.563 & 3.063 & 0.633 \\
2nd Thur & 5.380 & 5.469 & 3.500 & 6.563 & 3.063 & 0.653 \\
2nd Fri & 5.341 & 5.250 & 4.500 & 6.500 & 2.000 & 0.566 \\
2nd Mon & 5.392 & 5.375 & 4.500 & 6.563 & 2.063 & 0.570 \\
2nd Tues & 5.213 & 5.094 & 3.500 & 6.688 & 3.188 & 0.663 \\
2nd Wed & 5.192 & 5.125 & 4.000 & 6.875 & 2.875 & 0.723 \\
\hline
\end{tabular}

All numbers are expressed as percentage rates. 
Table 3

The influence of the switch to LRR on the closing fed funds rate behavior: Mean and Variance Equation Estimation Results for Closing Fed Funds Rates for the Period August 1, 1996 - July 6, 2000

\begin{tabular}{|c|c|c|c|c|c|c|}
\hline \multirow{2}{*}{$\begin{array}{l}\text { Mean Equation } \\
\text { Variable }\end{array}$} & \multicolumn{2}{|c|}{ Entire Sample } & \multicolumn{2}{|c|}{ CRR } & \multicolumn{2}{|c|}{ LRR } \\
\hline & Coefficient & z-Statistic & Coefficient & z-Stat & Coefficient & z-Stat \\
\hline Intercept & -0.0267 & -0.63 & -0.0181 & -1.40 & -0.0351 & -1.17 \\
\hline LagFF & $-0.3392^{\star \star \star}$ & -11.26 & $-0.2949^{\star * *}$ & -7.31 & $-0.3674^{\star \star \star}$ & -7.65 \\
\hline$\triangle T B$ & -0.3314 & -1.24 & $-0.4290^{* *}$ & -2.56 & 0.1381 & 0.82 \\
\hline $1^{\text {st }}$ Thurs & 0.0258 & 0.93 & $0.0878^{* *}$ & 2.36 & $0.1437^{* * *}$ & 5.83 \\
\hline $1^{\text {st }}$ Fri & $-0.0844^{\star *}$ & -1.98 & $-0.0993^{* * *}$ & -4.41 & $-0.0638^{\star \star \star}$ & -2.72 \\
\hline $2^{\text {nd }} F r i$ & -0.0170 & 0.64 & -0.0275 & -1.10 & -0.0154 & -0.58 \\
\hline SetWed & $0.1277^{* * *}$ & 3.17 & $0.1134^{* *}$ & 2.42 & -0.0328 & -1.09 \\
\hline Qend & $0.5639^{* *}$ & 2.54 & 0.1907 & 0.46 & 0.3754 & 1.36 \\
\hline Add & 0.0419 & 1.00 & $0.0534^{* * *}$ & 2.96 & 0.0444 & 1.49 \\
\hline Drain & 0.0098 & 0.24 & 0.0103 & 0.22 & $0.0921^{* *}$ & 2.35 \\
\hline Switch & -0.0297 & -0.61 & & & & \\
\hline$\triangle T B S$ witch & 0.3572 & 1.12 & & & & \\
\hline $1^{\text {st }}$ Thurs Switch & $0.1371^{* \star *}$ & 3.77 & & & & \\
\hline${ }^{1 \text { st }}$ FriSwitch & 0.0274 & 0.60 & & & & \\
\hline $2^{\text {nd }}$ FriSwitch & 0.0103 & 0.23 & & & & \\
\hline SetWedSwitch & $-0.1571^{\star * *}$ & -2.87 & & & & \\
\hline QendSwitch & -0.2513 & -0.66 & & & & \\
\hline AddSwitch & 0.0147 & 0.30 & & & & \\
\hline DrainSwitch & 0.0835 & 1.29 & & & & \\
\hline \multicolumn{7}{|c|}{ Variance equation } \\
\hline Intercept & $0.0392^{* * *}$ & 4.16 & 0.0014 & 0.70 & $0.0306^{\star * \star}$ & 4.67 \\
\hline $\mathrm{ARCH}$ term & $0.3439^{\star * \star}$ & 6.67 & $0.9771^{\star \star *}$ & 3.78 & $0.6388^{* * *}$ & 5.20 \\
\hline Asymmetric term & $-0.1285^{\star *}$ & -2.15 & $-0.9409^{\star \star \star}$ & -3.67 & $-0.3420^{* *}$ & -2.55 \\
\hline GARCH term & $0.3511^{* * *}$ & 7.43 & $0.1895^{\star * *}$ & 4.15 & $0.3261^{* \star *}$ & 4.81 \\
\hline$\triangle T B$ & -0.0303 & -0.42 & -0.0097 & -0.36 & -0.0011 & -0.04 \\
\hline $1^{\text {st }}$ Thurs & $-0.0549^{* * *}$ & -9.35 & -0.0068 & -0.54 & $-0.0268^{\star * *}$ & -4.93 \\
\hline $1^{s t} \mathrm{Fri}$ & -0.0106 & -1.20 & -0.0039 & -0.95 & $-0.0244^{\star * *}$ & -6.03 \\
\hline $2^{\text {nd }} F r i$ & $-0.0295^{\star \star \star}$ & -3.56 & -0.0032 & -0.91 & $-0.0279^{\star * *}$ & -6.04 \\
\hline SetWed & $0.0553^{\star \star *}$ & 5.10 & $0.0793^{\star * \star}$ & 4.16 & -0.0107 & -1.00 \\
\hline Qend & $0.2800^{* *}$ & 2.24 & $1.2541^{*}$ & 1.72 & $0.2555^{\star}$ & 1.78 \\
\hline Add & -0.0069 & -0.66 & $0.0279^{\star \star \star}$ & 9.69 & -0.0053 & -0.90 \\
\hline Drain & $-0.0235^{\star \star}$ & -2.17 & $0.0257^{\star *}$ & 1.96 & -0.0099 & -1.45 \\
\hline Switch & $-0.0227^{* *}$ & -2.40 & & & & \\
\hline$\triangle T B S w i t c h$ & -0.0120 & -0.15 & & & & \\
\hline${ }^{\text {st }}$ Thurs Switch & $0.0222^{\star * *}$ & 2.67 & & & & \\
\hline $1^{\text {st }}$ FriSwitch & -0.0010 & -0.10 & & & & \\
\hline $2^{\text {nd }}$ FriSwitch & 0.0071 & 0.78 & & & & \\
\hline SetWedSwitch & $-0.0452^{* *}$ & -2.55 & & & & \\
\hline QendSwitch & -0.0425 & -0.27 & & & & \\
\hline AddSwitch & 0.0141 & 1.30 & & & & \\
\hline DrainSwitch & $0.0331^{* *}$ & 2.13 & & & & \\
\hline
\end{tabular}


Table 4

The influence of the switch to LRR on the effective fed funds rate behavior: Mean and Variance Equation Estimation Results for Effective Fed Funds Rates for the Period August 1, 1996 - July

\section{6, 2000}

\begin{tabular}{|c|c|c|c|c|c|c|}
\hline Mean Equation & Entire S & iple & CR & & LR & \\
\hline Variable & Coefficient & z-Stat & Coefficient & z-Stat & Coefficient & z-Stat \\
\hline Intercept & $0.0297^{*}$ & 1.90 & 0.0213 & 0.83 & -0.0156 & -1.34 \\
\hline LagFF & $-0.2651^{* * *}$ & -7.84 & $-0.2501^{* \star \star}$ & -5.95 & $-0.3234^{\star \star *}$ & -6.86 \\
\hline$\triangle T B$ & 0.0220 & 0.14 & 0.1141 & 0.60 & 0.1034 & 0.92 \\
\hline $1^{\text {st }}$ Thurs & -0.0187 & -0.97 & -0.0278 & -1.23 & $0.0612^{* * *}$ & 4.09 \\
\hline $1^{s t} \mathrm{Fri}$ & $-0.1542^{* * *}$ & -8.32 & $-0.1406^{\star * *}$ & -4.93 & $-0.0843^{* * *}$ & -5.84 \\
\hline $2^{\text {nd }} F r i$ & $-0.0904^{* \star *}$ & -5.28 & $-0.0841^{\star \star *}$ & -3.59 & $-0.0325^{\star *}$ & -2.47 \\
\hline SetWed & $0.0812^{* * *}$ & 4.18 & $0.0819^{* * *}$ & 2.67 & 0.0043 & 0.27 \\
\hline Qend & $0.7401^{* * *}$ & 5.01 & $0.8529^{* * *}$ & 4.76 & 0.0703 & 0.47 \\
\hline Add & 0.0070 & 0.47 & 0.0072 & 0.30 & $0.0391^{* * *}$ & 3.29 \\
\hline Drain & 0.0013 & 0.07 & 0.0110 & 0.33 & $0.0417^{*}$ & 1.73 \\
\hline Switch & $-0.0391^{*}$ & -1.79 & & & & \\
\hline$\triangle T B S$ witch & 0.1320 & 0.71 & & & & \\
\hline $1^{\text {st }}$ Thurs Switch & $0.0749^{* * *}$ & 3.01 & & & & \\
\hline $1^{\text {st }}$ FriSwitch & $0.0736^{* * *}$ & 3.15 & & & & \\
\hline $2^{\text {nd }}$ FriSwitch & $0.0641^{* \star *}$ & 2.58 & & & & \\
\hline SetWedSwitch & $-0.0812^{* * *}$ & -3.35 & & & & \\
\hline QendSwitch & $-0.6719^{* * *}$ & -3.31 & & & & \\
\hline AddSwitch & 0.0227 & 1.08 & & & & \\
\hline DrainSwitch & $0.0576^{*}$ & $1.84^{*}$ & & & & \\
\hline Variance equation & & & & & & \\
\hline Intercept & $0.0091^{* * *}$ & 4.30 & $0.0207^{* * *}$ & 4.22 & $0.0032^{* * *}$ & 2.69 \\
\hline $\mathrm{ARCH}$ term & $0.7763^{* * *}$ & 5.30 & $0.2681^{* * *}$ & 2.95 & $0.7007^{* * *}$ & 4.08 \\
\hline Asymmetric term & $-0.5434^{\star * \star}$ & -3.69 & -0.1265 & -1.14 & $-0.4920^{\star * *}$ & -3.00 \\
\hline GARCH term & $0.2446^{* * *}$ & 6.96 & $0.3391^{* * *}$ & 2.85 & $0.3769^{\star * *}$ & 7.20 \\
\hline$\triangle T B$ & 0.0063 & 0.28 & -0.0004 & -0.01 & $-0.0484^{\star \star *}$ & -3.04 \\
\hline $1^{\text {st }}$ Thurs & $-0.0198^{\star \star \star}$ & -6.91 & $-0.0212^{* \star *}$ & -3.53 & $-0.0082^{* \star *}$ & -4.19 \\
\hline $1^{\text {st }}$ Fri & $-0.0073^{\star * \star}$ & -3.32 & $-0.0140^{\star * *}$ & -4.23 & -0.0032 & -1.58 \\
\hline $2^{\text {nd }} F r i$ & $-0.0102^{\star * *}$ & -3.45 & $-0.0198^{* * *}$ & -4.30 & $-0.0057^{* * *}$ & -3.97 \\
\hline SetWed & 0.0109 & 1.59 & 0.0046 & 0.56 & $-0.0060^{\star *}$ & -2.27 \\
\hline Qend & 0.3637 & 0.82 & 0.2011 & 0.95 & $0.1992^{* *}$ & 2.09 \\
\hline Add & $0.0074^{\star * *}$ & 3.60 & 0.0000 & 0.00 & $0.0051^{* * *}$ & 4.61 \\
\hline Drain & -0.0016 & -1.03 & $-0.0089^{* *}$ & -2.03 & $0.0122^{* *}$ & 2.04 \\
\hline Switch & 0.0010 & 0.37 & & & & \\
\hline$\triangle T B S w i t c h$ & -0.0402 & -1.44 & & & & \\
\hline $1^{\text {st }}$ Thurs Switch & $0.0101^{* \star *}$ & 2.82 & & & & \\
\hline $1^{\text {st }}$ FriSwitch & -0.0021 & -0.73 & & & & \\
\hline $2^{\text {nd }}$ FriSwitch & 0.0022 & 0.59 & & & & \\
\hline SetWedSwitch & $-0.0185^{\star *}$ & -2.49 & & & & \\
\hline QendSwitch & -0.1501 & -0.33 & & & & \\
\hline AddSwitch & $-0.0065^{\star *}$ & -2.31 & & & & \\
\hline DrainSwitch & 0.0081 & 1.32 & & & & \\
\hline
\end{tabular}


Table 5

The influence of sweep accounts on the fed funds rate behavior for the period July 7, 1994 through July 29, 1998.

\begin{tabular}{|c|c|c|c|c|}
\hline \multicolumn{5}{|c|}{ Mean and variance equations for the closing Fed funds rate } \\
\hline Mean equation & \multicolumn{2}{|c|}{ Closing Rates } & \multicolumn{2}{|c|}{ Effective Rates } \\
\hline Variable & Coefficient & z-Statistic & Coefficient & z-Statistic \\
\hline Intercept & -0.0352 & -0.66 & -0.0241 & -0.49 \\
\hline LagFF & $-0.3561^{* * *}$ & -9.36 & $-0.3438^{\star \star *}$ & -9.73 \\
\hline$\triangle T B$ & -0.1559 & -0.32 & 0.2941 & 0.92 \\
\hline 1st Thurs & 0.0389 & 0.60 & -0.0681 & -1.07 \\
\hline $1^{\text {st }} \mathrm{Fri}$ & $-0.1608^{*}$ & -1.84 & $-0.1717^{\star *}$ & -2.43 \\
\hline $2^{\text {nd }} F r i$ & -0.0187 & 0.18 & -0.0387 & -0.55 \\
\hline SetWed & $0.2689^{* * *}$ & 5.16 & $0.3041^{* * *}$ & 7.11 \\
\hline Qend & $0.4944^{* *}$ & 1.98 & $0.3751^{* * *}$ & 4.38 \\
\hline Add & 0.0340 & 0.61 & 0.0345 & 0.71 \\
\hline Drain & 0.0148 & 0.14 & 0.0718 & 0.83 \\
\hline Switch & 0.0265 & 0.32 & 0.0272 & 0.40 \\
\hline$\triangle T B S w i t c h$ & -0.3098 & -0.49 & -0.1666 & -0.41 \\
\hline $1^{\text {st }}$ Thurs Switch & -0.0176 & -0.22 & 0.0389 & 0.49 \\
\hline $1^{\text {st }}$ FriSwitch & 0.0718 & 0.72 & 0.0841 & 1.06 \\
\hline $2^{\text {nd }}$ FriSwitch & -0.0676 & -0.60 & -0.0269 & -0.33 \\
\hline SetWedSwitch & $-0.2016^{\star \star}$ & -2.27 & $-0.2712^{\star \star \star}$ & -4.59 \\
\hline QendSwitch & 0.0781 & 0.09 & $0.5565^{\star * *}$ & 5.12 \\
\hline AddSwitch & -0.0079 & -0.10 & -0.0228 & -0.34 \\
\hline DrainSwitch & 0.0056 & 0.04 & -0.0529 & -0.52 \\
\hline \multicolumn{5}{|c|}{ Variance equation } \\
\hline Intercept & $0.0823^{\star \star *}$ & 4.39 & $0.0326^{\star \star \star}$ & 3.26 \\
\hline $\mathrm{ARCH}$ term & $0.2169^{* * *}$ & 4.88 & $0.1469^{\star \star *}$ & 2.82 \\
\hline Asymmetric term & $-0.1267^{\star *}$ & -2.27 & 0.0460 & 0.51 \\
\hline GARCH term & $0.4413^{\star \star \star}$ & 5.94 & $0.5668^{\star \star \star}$ & 10.95 \\
\hline$\triangle T B$ & 0.0929 & 0.63 & 0.0063 & 0.10 \\
\hline $1^{\text {st }}$ Thurs & $-0.0673^{\star * *}$ & -2.80 & -0.0117 & -0.53 \\
\hline $1^{s t} \mathrm{Fri}$ & -0.0367 & -1.08 & -0.0179 & -0.76 \\
\hline $2^{\text {nd }} F r i$ & -0.0280 & -0.74 & -0.0119 & -0.57 \\
\hline SetWed & $0.0737^{\star \star \star}$ & 3.41 & 0.0003 & 0.03 \\
\hline Qend & $0.2472^{* * *}$ & 3.00 & 0.0113 & 0.35 \\
\hline Add & -0.0149 & -0.80 & -0.0026 & -0.27 \\
\hline Drain & -0.0213 & -0.66 & -0.0073 & -0.46 \\
\hline Switch & -0.0078 & -0.39 & -0.0030 & -0.26 \\
\hline$\triangle T B S w i t c h$ & -0.0404 & -0.23 & -0.0144 & -0.16 \\
\hline $1^{\text {st }}$ Thurs Switch & -0.0214 & -0.80 & -0.0032 & -0.13 \\
\hline $1^{\text {st }}$ FriSwitch & -0.0134 & -0.38 & -0.0102 & -0.40 \\
\hline $2^{\text {nd }}$ FriSwitch & -0.0499 & -1.20 & -0.0251 & -0.97 \\
\hline SetWedSwitch & -0.0186 & -0.58 & -0.0132 & -0.73 \\
\hline QendSwitch & 0.4076 & 1.28 & 0.0171 & 0.44 \\
\hline AddSwitch & -0.0106 & -0.46 & -0.0036 & -0.32 \\
\hline DrainSwitch & -0.0081 & -0.23 & -0.0084 & -0.49 \\
\hline
\end{tabular}

***Significant at the 0.01 level, ** Significant at the 0.05 level, *Significant at the 0.1 level 
Figure 1.

Monthly Average of Daily Fed Funds Rates

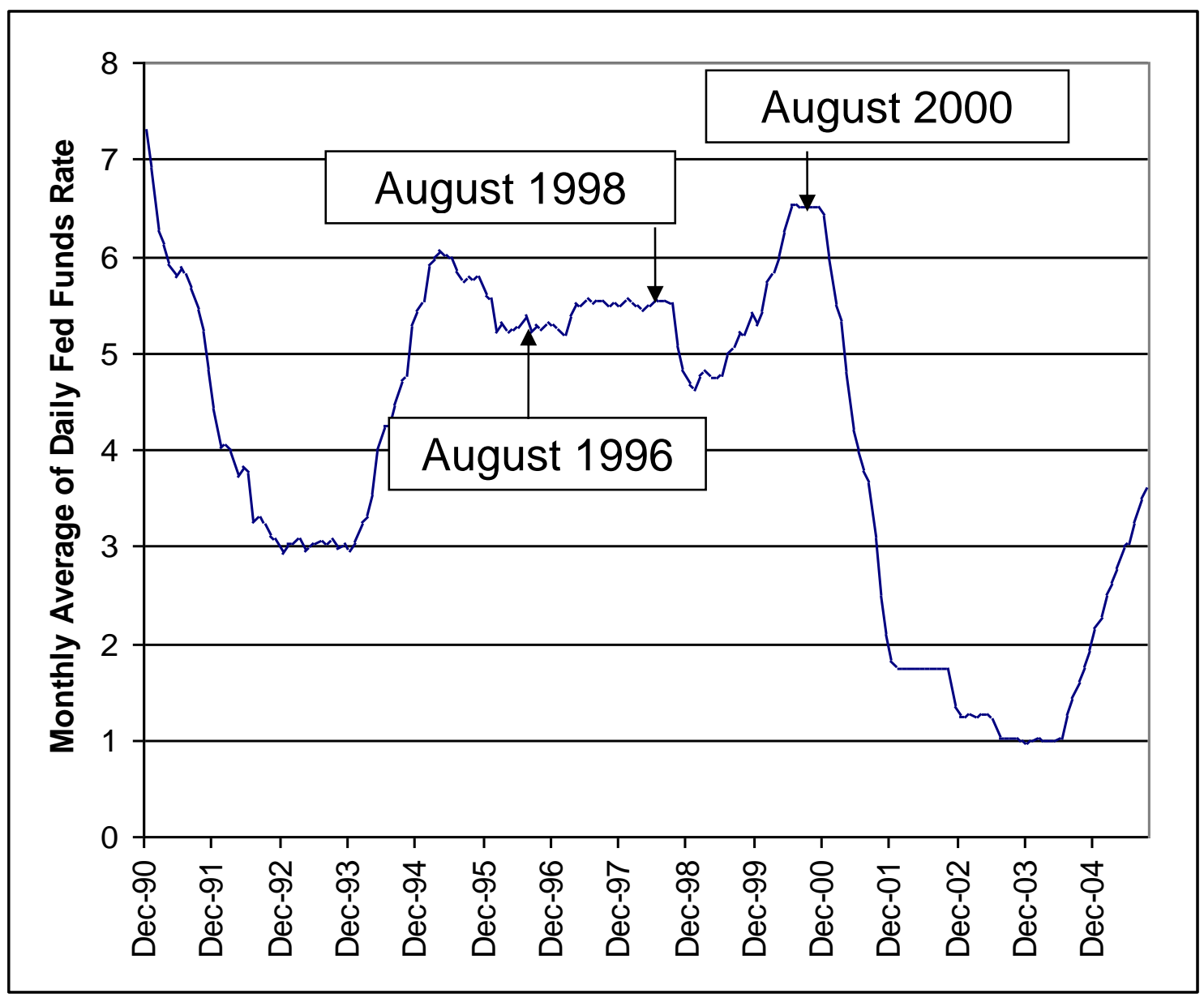


Figure 2

Plot of Daily Average Fed Funds Rate (from Table 2) Across the Maintenance Period under CRR and LRR

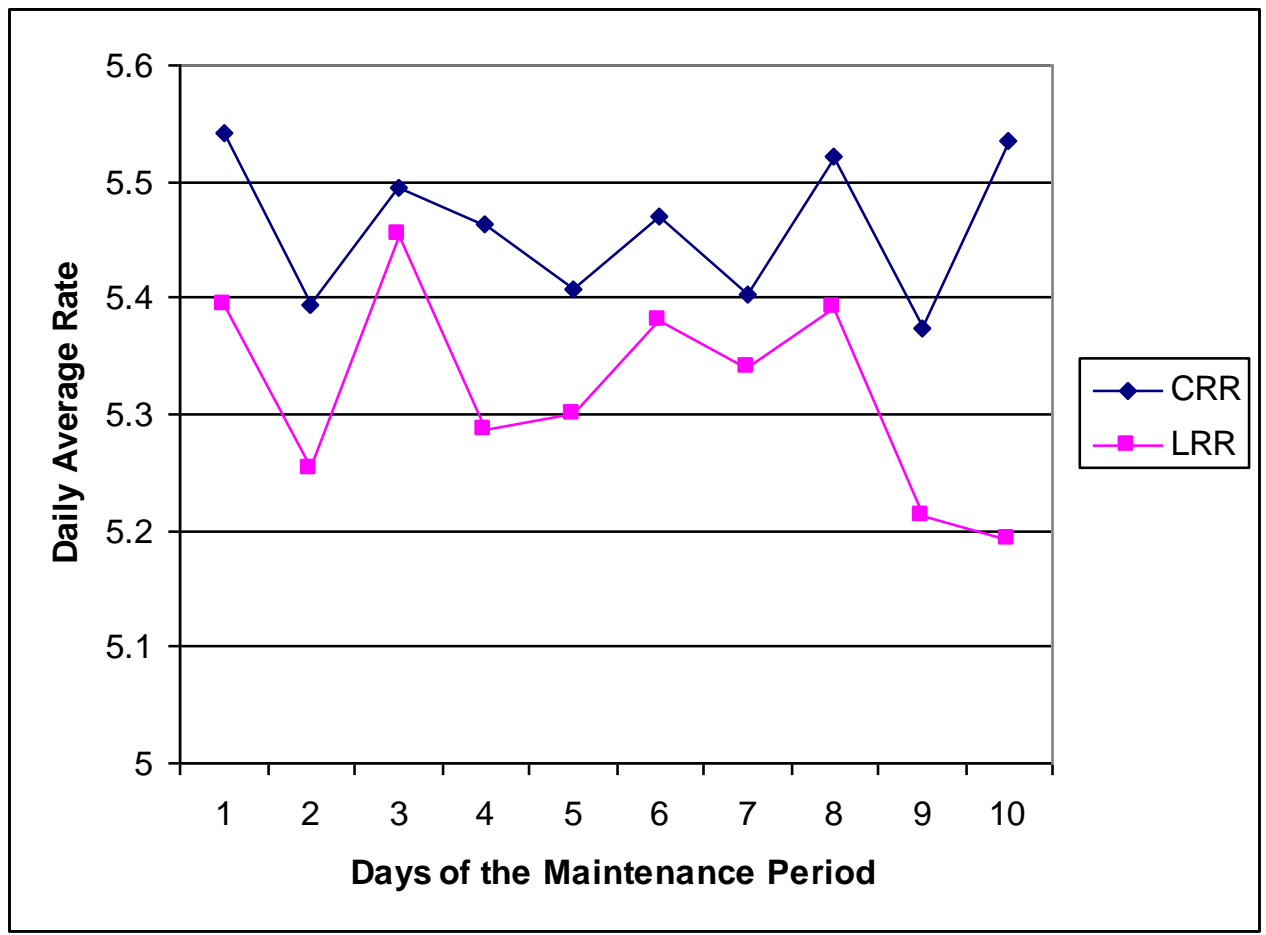


Return to Lagged Reserve Requirements

Figure 3

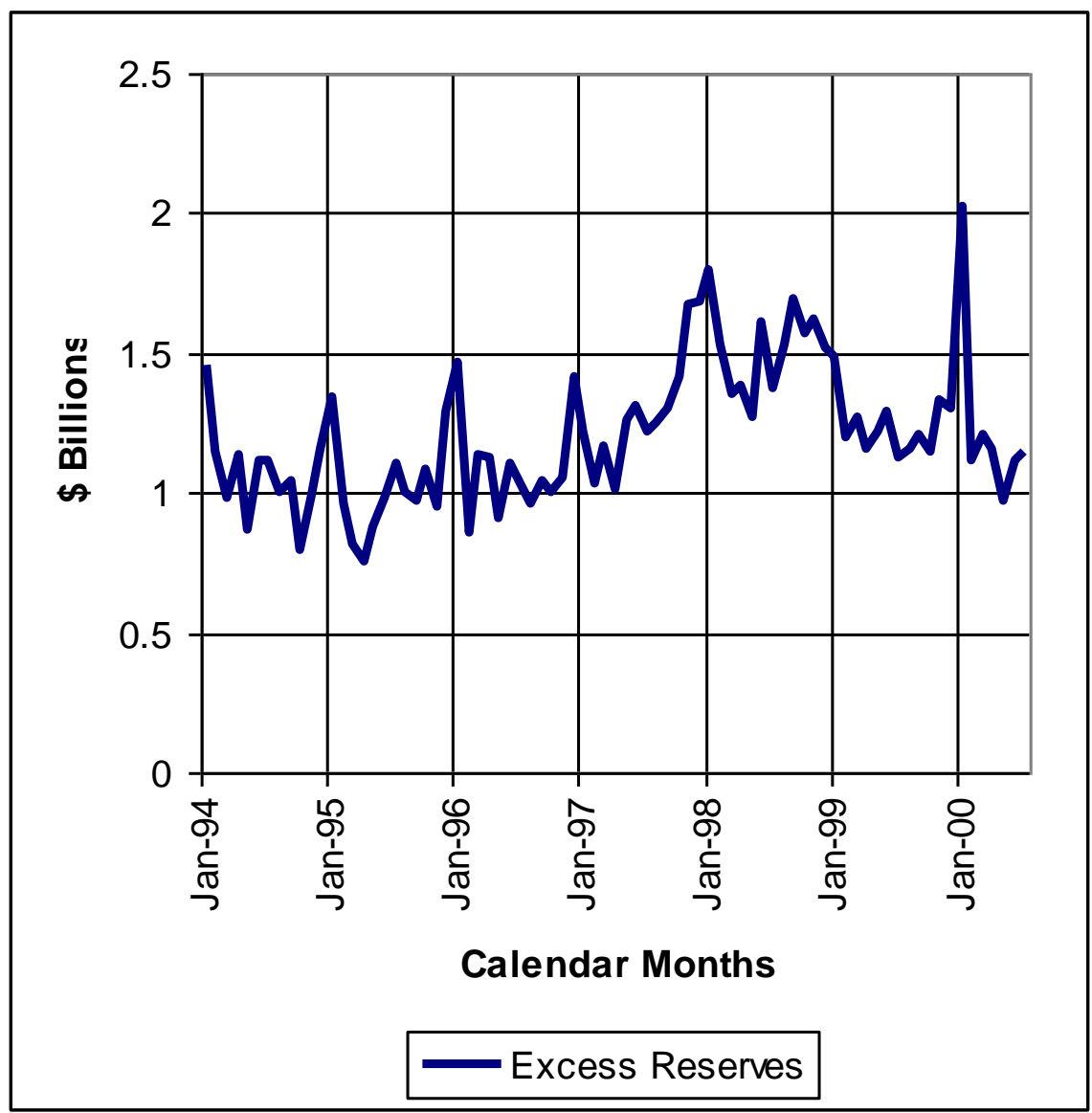


Figure 4

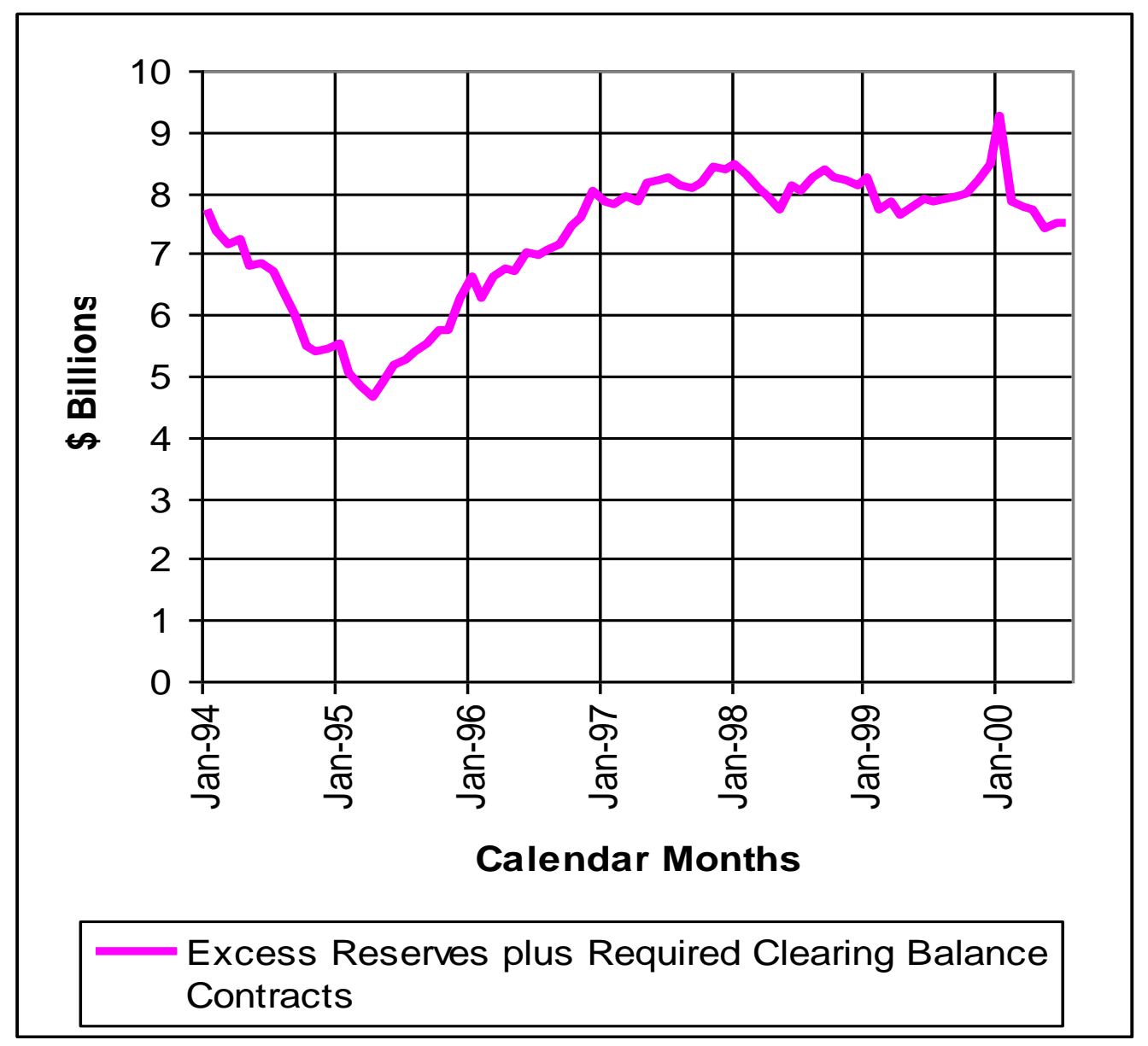

